\title{
Lactose hydrolysis potential and thermal stability of commercial $\beta$-galactosidase in UHT and skimmed milk
}

\author{
Alessandra $\mathrm{BOSSO}^{1 \star}$, Luiz Rodrigo Ito MORIOKA ${ }^{1}$, Leandro Freire dos SANTOS ${ }^{2}$, Hélio Hiroshi SUGUIMOTO ${ }^{1}$
}

\begin{abstract}
The commercial enzyme (E.C. = 3.2.1.23) from Kluyveromyces lactis (liquid) and Aspergillus oryzae (lyophilized) was investigated for its hydrolysis potential in lactose substrate, UHT milk, and skimmed milk at different concentrations (0.7; 1.0 and $1.5 \%)$, $\mathrm{pH}$ values $\left(5.0 ; 6.0 ; 6.5\right.$ and 7.0), and temperature $\left(30 ; 35 ; 40\right.$ and $\left.55^{\circ} \mathrm{C}\right)$. High hydrolysis rates were observed for the enzyme from $K$. lactis at pH 7.0 and $40^{\circ} \mathrm{C}$, and from $A$. oryzae at pH 5.0 and $55^{\circ} \mathrm{C}$. The enzyme from $K$. lactis showed significantly higher hydrolysis rates when compared to A. oryzae. The effect of temperature and $\beta$-galactosidase concentration on the lactose hydrolysis in UHT milk was higher than in skimmed milk, for all temperatures tested. With respect to the thermal stability, a decrease in hydrolysis rate was observed at $\mathrm{pH} 6.0$ at $35^{\circ} \mathrm{C}$ for $\mathrm{K}$. lactis enzyme, and at $\mathrm{pH} 6.0$ at $55{ }^{\circ} \mathrm{C}$ for the enzyme from $A$. oryzae. This study investigate the hydrolysis of $\beta$-galactosidase in UHT and skimmed milk. The knowledge about the characteristics of the $\beta$-galactosidase from $K$. lactis and A. oryzae enables to use it most efficiently to control the enzyme concentration, temperature, and $\mathrm{pH}$ in many industrial processes and product formulations.
\end{abstract}

Keywords: UHT and skimmed milk; $\beta$-galactosidase; enzymatic characterization; lactose intolerance; enzyme activity.

Practical Application: Lactose hydrolysis potential and thermal stability of commercial $\beta$-galactosidase.

\section{Introduction}

Milk is considered a high biological value and nutritional energy food, recommended for all age groups and essential for newborns and infants (Borges et al., 2000; Ferreira, 1997).

Lactose is found in milk in larger amounts (Carminatti, 2001; Hobman, 1984). In the human intestine, lactose is hydrolyzed by $\beta$-galactosidase, being absorbed as glucose and galactose, thus facilitating its absorption in the body (Bódalo et al., 1991; Zadow, 1984). In lactose-intolerant individuals, hydrolysis of lactose alleviates symptoms of gastrointestinal disorders (Manan et al., 1999; McSweeney \& Fox, 2009). Lactose can be hydrolyzed using acid treatments (Jelen, 1983; Goursaud, 1985) or enzymatic catalysis by the enzyme $\beta$-galactosidase. Enzymatic hydrolysis can be performed in UHT milk and skimmed milk without prior processing, preserving the nutritional properties of the resulting products (Santos et al., 1998; Vitolo, 2001, Hronska et al., 2009, Pereira et al., 2012). Thus, the commercial importance of $\beta$-galactosidase is its application in the dairy industry to obtain low lactose products, ideal for intolerant consumers (Haider \& Husain, 2008; Jurado et al., 2002; Kardel et al., 1995; Mahoney, 1997; Pivarnik et al., 1995).

However, the $\beta$-galactosidase activity can be affected by several factors, including temperature, $\mathrm{pH}$, pressure, concentration of reactants (Evangelista, 1998), and presence of metal ions (Carminatti, 2001). Furthermore, depending on the source of extraction (vegetable, animal or microorganism), $\beta$-galactosidase may exhibit different properties with a variety of potential technological applications (Oliveira, 2005). According to Şener et al. (2006), enzymes extracted from filamentous fungi have higher activity at acidic $\mathrm{pH}$, since the yeasts present better operating conditions at neutral $\mathrm{pH}$ and milder temperatures.

In this context, the knowledge about the best activity conditions of this enzyme extracted from different microorganisms is of great importance, aiming at more effective commercial applications, especially in the dairy and pharmaceutical industry. Therefore, the aim of this study was to evaluate the effect of the commercial enzyme $\beta$-galactosidase from the yeast Kluyveromyces lactis and the filamentous fungus Aspergillus oryzae on the hydrolysis of UHT milk and skimmed milk at different enzyme concentrations, temperature, and $\mathrm{pH}$ conditions.

\section{Materials and methods}

\subsection{Enzymes}

The enzymes used in the hydrolysis reactions were commercial $\beta$-galactosidase from microbial origin in liquid and lyophilized forms. The liquid enzyme MAXILACT ${ }^{\circledR}$ LX5000 (Sedim Cedex - France) was obtained from the yeast Kluyveromyces lactis, and the lyophilized enzyme Bio-Cat INC/USA was obtained from the fungus Aspergillus oryzae, according to information provided by the manufacturer. Both enzymes had lactase activity of 5000 ALU. 


\subsection{Effect of $\beta$-galactosidase concentration, temperature, and $\mathrm{pH}$ on the hydrolysis of lactose substrate, UHT milk and skimmed milk}

The hydrolysis reactions were performed using $5 \%(\mathrm{w} / \mathrm{v})$ lactose in potassium phosphate monobasic buffer for the enzyme from $K$. lactis and sodium acetate buffer for the enzyme from A. oryzae. The variables tested were enzyme concentration $(0.7,1.0$, and $1.5 \%)$, temperature $\left(30,35,40\right.$, and $\left.55^{\circ} \mathrm{C}\right)$ and $\mathrm{pH}(5.0,6.0,6.5$, and 7.0$)$.

For lactose hydrolysis, $100 \mathrm{~mL}$ of UHT milk and skimmed milk (Cativa - Londrina, Parana, Brazil) were used under the same conditions described above. All analyses were performed in triplicate.

\subsection{Thermal stability}

The optimum enzyme concentration, temperature, and $\mathrm{pH}$ for each enzyme were defined according to the trials performed in Section 2.2. To evaluate the thermal stability, 1.5\% of each enzyme was mixed with $100 \mathrm{~mL}$ of buffer solution in Erlenmeyer flasks of $250 \mathrm{~mL}$. The flasks were incubated in water baths at various temperatures, as shown in Table 1. Every 30 minutes during 300 minutes, a flask was removed from water bath, 5\% lactose was added, and the flask was placed again in the water bath for 15 minutes for lactose hydrolysis. Then, the analysis was performed according to the analytical determinations described in section 2.4.

\subsection{Analytical determination}

To determine the degree of hydrolysis, $2 \mathrm{~mL}$ sample was collected and placed in boiling water bath for 5 minutes, and then on ice-bath for 3 minutes to inactivate the enzyme. Glucose was determined by the glucose-oxidase method using the kit Glucose PP (Analysa ${ }^{\circledR}$ ). Lactose was determined in milk by the phenol-sulfuric method, adapted by DuBois et al. (1956).

\subsection{Statistical analysis}

Data were analyzed by Statistic software 10.0 (Statsoft, 2007). Differences between means were analyzed by Tukey's test at a significance level of $5 \%(\mathrm{P}<0.05)$.

\section{Results and discussion}

\subsection{Effect of $\beta$-galactosidase concentration, temperature, and $\mathrm{pH}$ on the hydrolysis of the lactose substrate}

The commercial $\beta$-galactosidase from K. lactis and A. oryzae exhibited optimum activities under different reaction conditions, and lactose hydrolysis increased with the increase in enzyme

Table 1. Experimental conditions to evaluate the thermal stability of the enzymes from $K$. lactis and A. oryzae.

\begin{tabular}{lcc}
\hline & K. lactis & A. oryzae \\
\hline Buffer & Potassium phosphate & Sodium acetate \\
Enzyme concentration (\%) & 1.5 & 1.5 \\
$\mathrm{Ph}$ & 6.0 & 5.0 \\
Temperature $\left({ }^{\circ} \mathrm{C}\right)$ & $30,35,40$ & $50,55,60$ \\
\hline
\end{tabular}

concentration. Therefore, only the concentration of $1.5 \%$ was used for both enzymes, once the highest enzyme activity was observed at this concentration. At 30,35 , and $40^{\circ} \mathrm{C}$ and $\mathrm{pH} 6.0,6.5$, and 7.0, significant lactose hydrolysis rates $(\mathrm{p}<0.05)$ were observed for the enzyme from $K$. lactis when compared to A. oryzae, with no activity at $\mathrm{pH} 5.0$, demonstrating its sensitivity at low $\mathrm{pH}$ values (Figure 1A). At pH 7.0 and $40{ }^{\circ} \mathrm{C}$, high hydrolysis rate (97.9\%) was observed for the enzyme from K. lactis, as shown in Figure 1D. In general, the enzyme from $K$. lactis was sensitive to temperatures above $40^{\circ} \mathrm{C}$, with complete inactivation at $55^{\circ} \mathrm{C}$ at all $\mathrm{pH}$ ranges studied.

High hydrolysis rates were observed for the enzyme from A. oryzae at $\mathrm{pH} 5.0$, with percentages of $42.9,46.8,52.1$, and $67.4 \%$ at $30,35,40$, and $55^{\circ} \mathrm{C}$, respectively (Figure $1 \mathrm{~A}$ ). Similar hydrolysis profiles were observed at $\mathrm{pH} 6.0$ and 6.5 , but with lower percentages of hydrolysis (Figure $1 \mathrm{~B}$ and $\mathrm{C}$ ). In contrast, lower rates (20\%) were observed at $\mathrm{pH} 7.0$ for the enzyme from A. oryzae, as shown in Figure 1D.

Higher hydrolysis rate $(4.54 \%$ / $\mathrm{min})$ occurred at $\mathrm{pH} 6.0$ and $40^{\circ} \mathrm{C}$ for the enzyme from $K$. lactis in the first 15 minutes of reaction, while lower rate $(2.30 \% / \mathrm{min})$ was observed at similar $\mathrm{pH}$ at $35^{\circ} \mathrm{C}$. Trindade et al. (2004) found higher hydrolysis rates at $40^{\circ} \mathrm{C}$ and $\mathrm{pH} 6.6$ using the enzyme from $K$. lactis in free form, similar to the conditions obtained in this experiment. For the enzyme from $A$. oryzae, no differences were observed in the rate of hydrolysis, with high enzyme activity at $\mathrm{pH} 5.0$ and $55^{\circ} \mathrm{C}$ $(2.20 \% / \mathrm{min})$. Guidini et al. (2010) evaluated the immobilized $\beta$-galactosidase from A. oryzae and found similar results of this study. Ribeiro et al. (2005) observed maximum activity at $\mathrm{pH}$ from 4.5 to 4.8 , which decreased at different $\mathrm{pH}$ values, with stability at $\mathrm{pH} 3.0$ to 6.0. Regarding the temperature, the same authors observed higher enzyme activity at $55^{\circ} \mathrm{C}$, followed by gradual thermal inactivation up to complete loss of activity at $70^{\circ} \mathrm{C}$.

\subsection{Effects of temperature and $\beta$-galactosidase concentration on the hydrolysis of UHT milk and skimmed milk}

Lactose hydrolysis in UHT milk was higher than in skimmed milk for both enzymes, probably due to the higher fat content in UHT milk.

For the enzyme from K. lactis, a significant difference $(\mathrm{P}<0.05)$ was observed between milk samples, once $100 \%$ hydrolysis was observed in UHT milk at 35 and $40{ }^{\circ} \mathrm{C}$, against $92.49 \%$ in skimmed milk at $40{ }^{\circ} \mathrm{C}$ (Table 2). Campos et al. (2009) found $90 \%$ hydrolysis in UHT milk after 5 hours of reaction, at temperatures ranging from 30 to $40{ }^{\circ} \mathrm{C}$. In general, lower hydrolysis rates were observed for the enzyme from $A$. oryzae with values of $41.34 \%$ and $32.7 \%$ in UHT milk and skimmed milk at $55^{\circ} \mathrm{C}$, respectively (Table 2), probably due to the $\mathrm{pH} 6.5$, once the enzyme activity is optimized at $\mathrm{pH} 5.0$, and decreases at $\mathrm{pH}$ above 6.0. Guidini et al. (2011) evaluated the $\beta$-galactosidase from A. oryzae in free and immobilized forms with glutaraldehyde, and found a decrease of $56.42 \%$ at pH 1.0 to 5.0 , and $13.46 \%$ at $\mathrm{pH} 5.0$ to 8.0 for the enzyme in free form, while a great stability was observed for the immobilized enzyme at all $\mathrm{pH}$ values (1.0 to 8.0), evidencing that the immobilization process is effective to maintain the enzyme stability. 


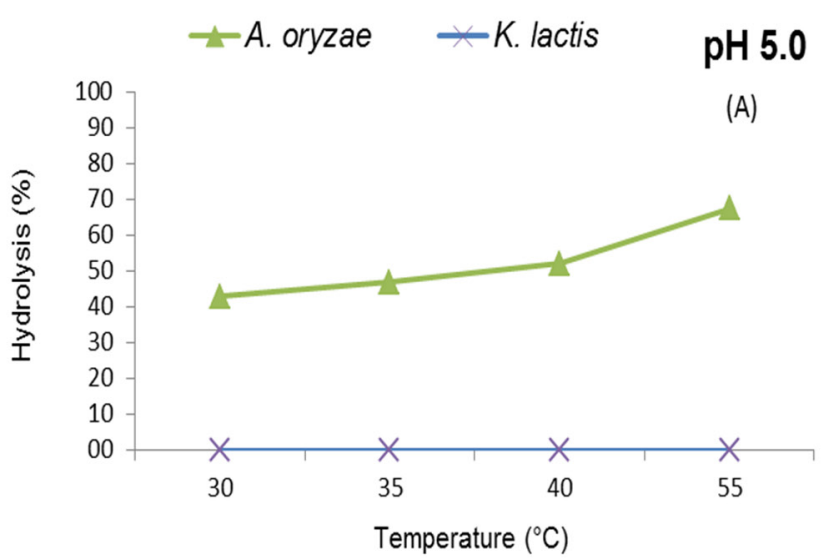

$\mathrm{pH} 6.5$

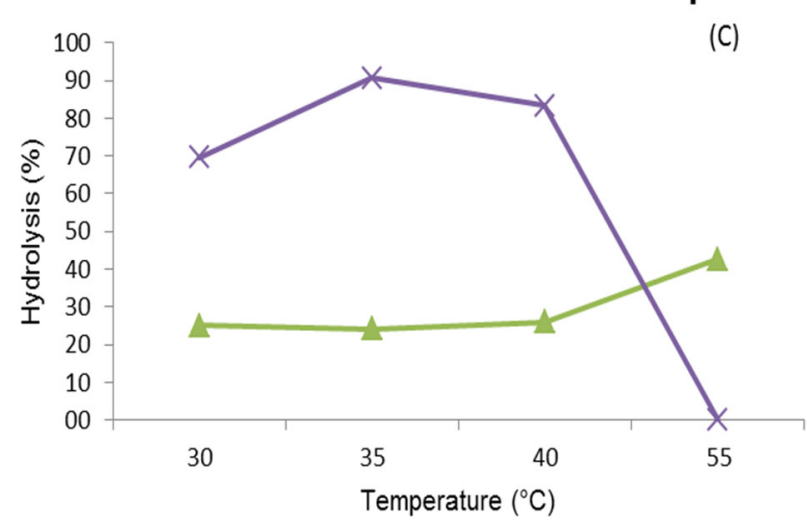

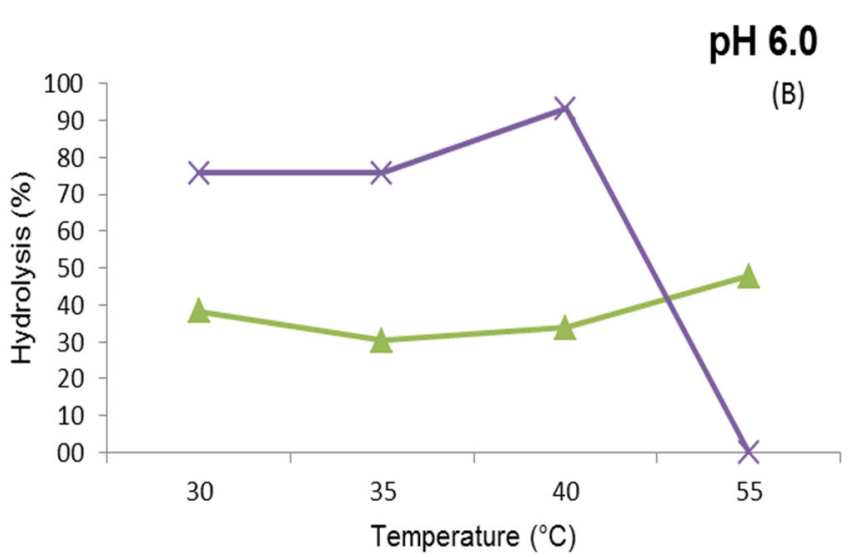

$\mathrm{pH} 7.0$

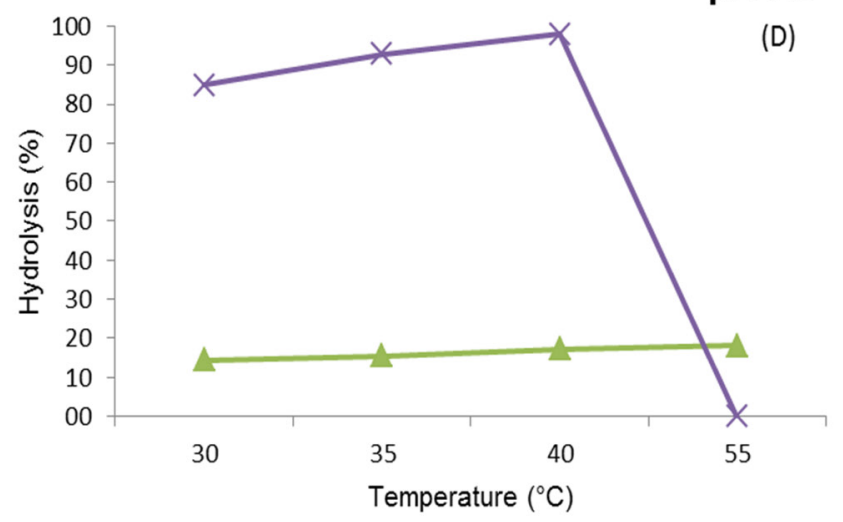

Figure 1. Lactose hydrolysis by the enzymes from K. lactis and A. oryzae at different temperatures and pH 5.0 (A), 6.0 (B), 6.5 (C), and 7.0 (D).

Table 2. Lactose hydrolysis by the enzymes from K. lactis and A. oryzae in UHT milk and skimmed milk at different temperatures.

\begin{tabular}{|c|c|c|c|c|}
\hline \multirow{3}{*}{ Temperature } & \multicolumn{4}{|c|}{ Hydrolysis $(\%)^{\star}$} \\
\hline & \multicolumn{2}{|c|}{ UHT milk } & \multicolumn{2}{|c|}{ Skimmed milk } \\
\hline & K. lactis & A.oryzae & K. lactis & A.oryzae \\
\hline $30^{\circ} \mathrm{C}$ & $86.42 \pm 1.029^{\mathrm{cA}}$ & $28.89 \pm 0.674^{\mathrm{cC}}$ & $78.85 \pm 0.998^{\mathrm{cB}}$ & $16.28 \pm 0.496^{\mathrm{dD}}$ \\
\hline $35^{\circ} \mathrm{C}$ & $100.0 \pm 1.666^{\mathrm{aA}}$ & $26.99 \pm 0.190 \mathrm{dC}$ & $86.43 \pm 1.001^{\mathrm{bB}}$ & $19.14 \pm 0.421^{\mathrm{cD}}$ \\
\hline $40^{\circ} \mathrm{C}$ & $100.0 \pm 0.425^{\mathrm{bA}}$ & $32.91 \pm 0.577^{\mathrm{bC}}$ & $92.49 \pm 0.669$ ав & $21.12 \pm 0.257^{b D}$ \\
\hline $55^{\circ} \mathrm{C}$ & $40.61 \pm 0.220 \mathrm{~dB}$ & $41.34 \pm 0.421^{\mathrm{aA}}$ & $18.60 \pm 0.060 \mathrm{dD}$ & $32.70 \pm 0.651^{\mathrm{aC}}$ \\
\hline
\end{tabular}

${ }^{*}$ Means followed by the same uppercase letter on the same line, and lowercase letter in the same column do not differ significantly among treatments, by Tukey's test $(\mathrm{P}<0.05)$.

The higher hydrolysis rates for the enzyme from $K$. lactis were observed in UHT milk and skimmed milk at $40{ }^{\circ} \mathrm{C}$, with $4.29 \% / \mathrm{min}$ and $3.28 \% / \mathrm{min}$, respectively, in the first 15 minutes of reaction. For the enzyme from $A$. oryzae, higher rates were observed in UHT and skim milk at $55^{\circ} \mathrm{C}$, with $1.72 \% / \mathrm{min}$ and $1.08 \% / \mathrm{min}$, respectively (Figure 2 ).

\subsection{Thermal stability of the enzymes}

The higher inactivation rate of $\beta$-galactosidase from $K$. lactis was directly proportional to the raise in temperature, especially from $40{ }^{\circ} \mathrm{C}$. The enzyme from $A$. oryzae proved to be more resistant to higher temperatures, reinforcing the results obtained in the previous tests. A negative linear correlation was observed between the reaction time and the rate of hydrolysis for the enzyme from $K$. lactis at 30 to $35^{\circ} \mathrm{C}$, while a strong negative correlation was observed for the enzyme from A. oryzae at all temperatures (Figure $3 \mathrm{~A}$ and $\mathrm{B}$ ). At $30^{\circ} \mathrm{C}$, the enzyme from $K$. lactis showed inactivation rate of $0.12 \% / \mathrm{min}$ and activity of $46.2 \%$ at the end of 300 minutes, while at $35^{\circ} \mathrm{C}$, the inactivation rate was $0.18 \% / \mathrm{min}$ and $35.4 \%$. At $40{ }^{\circ} \mathrm{C}$, the enzyme was inactivated almost completely $(94.8 \%)$ in the first 60 minutes of reaction, with inactivation rate of $1.45 \% / \mathrm{min}$. A significant loss of enzyme activity was observed for the enzyme from $K$. lactis in the first 60 minutes for all temperature conditions (Figure 3 ). For the enzyme from $A$. oryzae, the reduction of activity during storage was less intense when compared to the enzyme from $K$. lactis. When subjected to $50{ }^{\circ} \mathrm{C}$, the enzyme activity reduced $17.7 \%$ after 300 minutes, which is equivalent to 


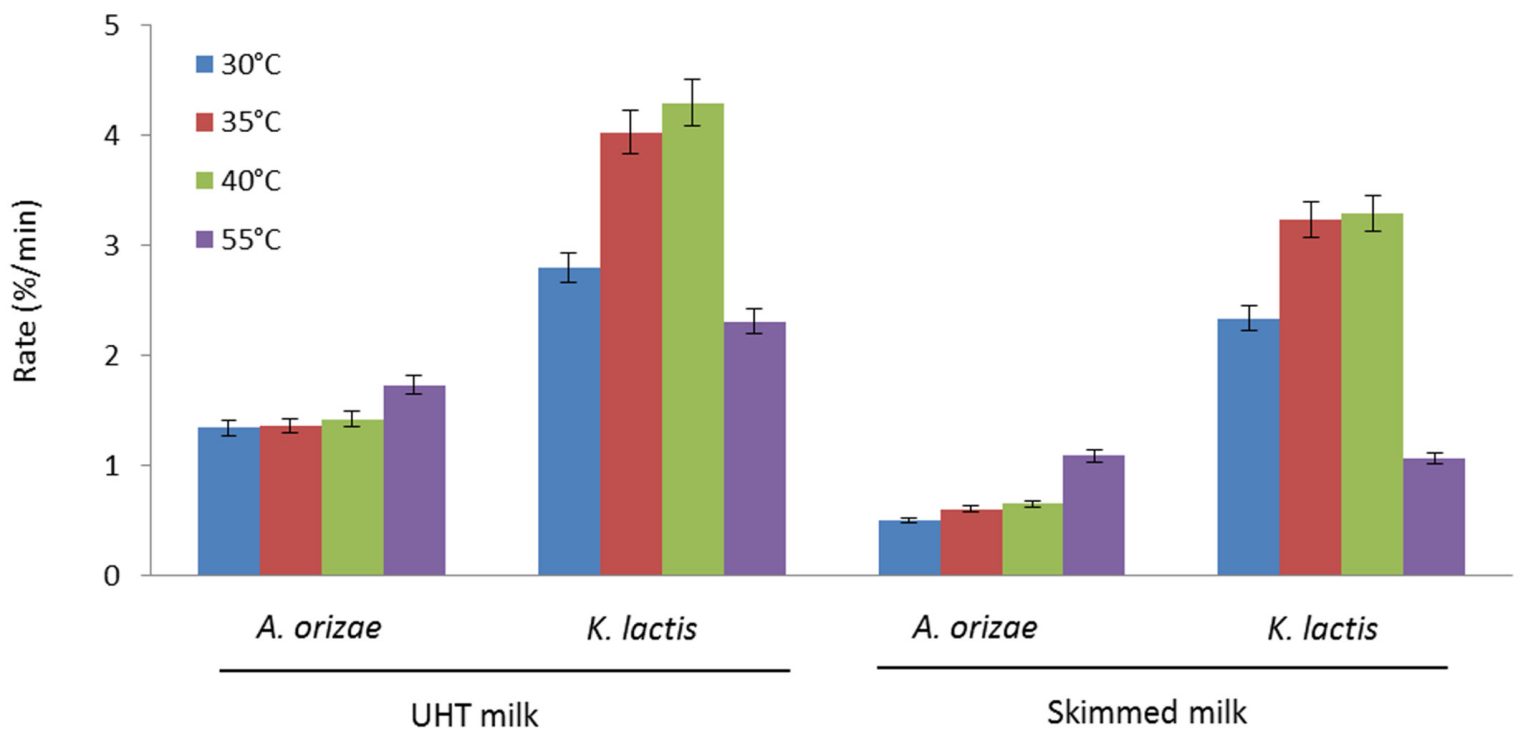

Figure 2. Rate of lactose hydrolysis (in the first 15 min of reaction) in UHT milk and skimmed milk subjected to different temperatures.
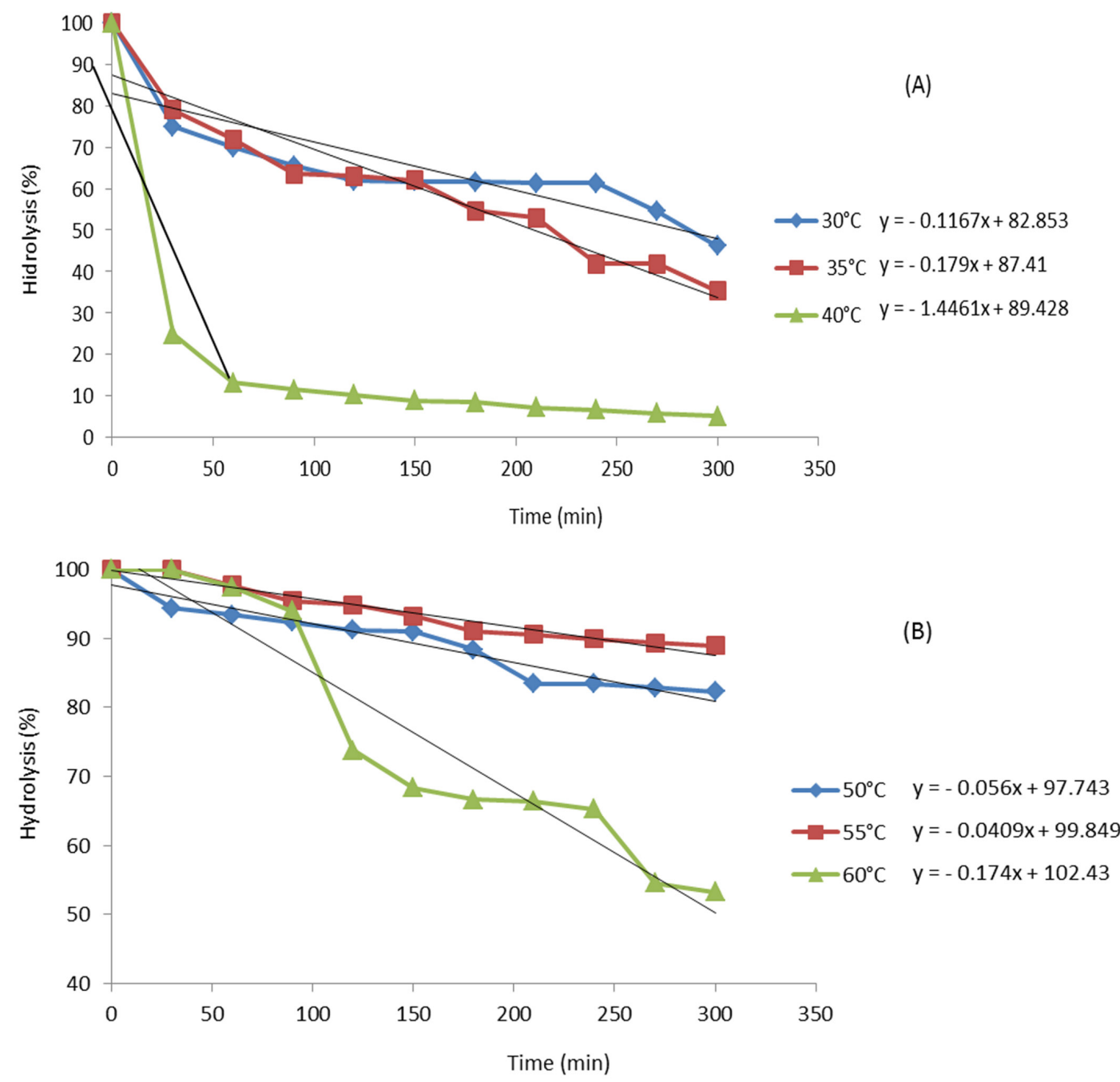

Figure 3. Rate of lactose hydrolysis by the enzymes from K. lactis (A) and A. oryzae (B) at different temperatures, and loss of enzyme activity during storage. No linear correlation was observed for the enzyme from $\mathrm{K}$. lactis at $40^{\circ} \mathrm{C}$. 
Bosso et al.

Table 3. Lactose hydrolysis by the enzyme from K. lactis as a function of time and temperature of storage.

\begin{tabular}{cccc}
\hline Time (minutes) & $30^{\circ} \mathrm{C}$ & $35^{\circ} \mathrm{C}$ & $40^{\circ} \mathrm{C}$ \\
\hline 0 & $68.476 \pm 0.621^{\mathrm{a} *}$ & $68.476 \pm 0.621^{\mathrm{a}}$ & $68.476 \pm 0.621^{\mathrm{a}}$ \\
60 & $51.304 \pm 1.243^{\mathrm{b}}$ & $54.061 \pm 1.422^{\mathrm{b}}$ & $17.058 \pm 0.264^{\mathrm{b}}$ \\
90 & $47.938 \pm 0.298 \mathrm{c}$ & $49.259 \pm 0.257^{\mathrm{c}}$ & $9.058 \pm 0.387^{\mathrm{c}}$ \\
120 & $45.306 \pm 1.234^{\mathrm{d}}$ & $43.472 \pm 0.128^{\mathrm{d}}$ & $7.915 \pm 0.146^{\mathrm{d}}$ \\
150 & $42.372 \pm 0.298^{\mathrm{e}}$ & $43.129 \pm 1,047^{\mathrm{d}}$ & $7.026 \pm 0.073^{\mathrm{e}}$ \\
180 & $42.286 \pm 0.197^{\mathrm{e}}$ & $42.443 \pm 0,771^{\mathrm{d}}$ & $6.137 \pm 0.073 \mathrm{f}$ \\
210 & $42.200 \pm 0.224^{\mathrm{e}}$ & $37.427 \pm 0,385^{\mathrm{e}}$ & $5.798 \pm 0.146^{\mathrm{f}}$ \\
240 & $42.027 \pm 0.325^{\mathrm{e}}$ & $36.312 \pm 1.479^{\mathrm{e}}$ & $4.994 \pm 0.146^{\mathrm{g}}$ \\
270 & $41.984 \pm 0.523^{\mathrm{e}}$ & $28.681 \pm 0.680^{\mathrm{f}}$ & $4.571 \pm 0.219^{\mathrm{gh}}$ \\
300 & $37.324 \pm 1.608^{\mathrm{f}}$ & $28.681 \pm 0,000^{\mathrm{f}}$ & $4.021 \pm 0.073^{\mathrm{hi}}$ \\
\hline
\end{tabular}

${ }^{\star}$ Means followed by the same letter in the same column do not differ significantly by Tukey's test $(\mathrm{P}>0.05)$.

Table 4. Lactose hydrolysis by the enzyme from A. oryzae as a function of time and temperature of storage.

\begin{tabular}{|c|c|c|c|}
\hline Time (minutes) & $50^{\circ} \mathrm{C}$ & $55^{\circ} \mathrm{C}$ & $60^{\circ} \mathrm{C}$ \\
\hline 0 & $32.991 \pm 0.125^{\text {a }}$ & $32.991 \pm 0.125^{\text {bcd }}$ & $32.991 \pm 0.125^{\mathrm{a}}$ \\
\hline 30 & $30.730 \pm 0.683^{b}$ & $34.888 \pm 0.708^{a}$ & $33.470 \pm 1.267^{\mathrm{a}}$ \\
\hline 60 & $30.808 \pm 0.136^{b}$ & $34.073 \pm 0.642^{\mathrm{ab}}$ & $32.625 \pm 0.445^{\mathrm{a}}$ \\
\hline 90 & $30.4539 \pm 0.3615^{b}$ & $33.3022 \pm 0.0000 \mathrm{abc}$ & $31.4421 \pm 0.5071^{\mathrm{a}}$ \\
\hline 120 & $30.0988 \pm 0.1808^{b}$ & $33.0879 \pm 0.1964 \mathrm{abcd}$ & $24.6804 \pm 0.4075^{b}$ \\
\hline 150 & $30.0199 \pm 1.4119^{b}$ & $32.5307 \pm 1.1572$ bcde & $22.8632 \pm 1.1077^{b c}$ \\
\hline 180 & $29.1521 \pm 0.1808^{b c}$ & $31.7593 \pm 1.0042^{\mathrm{cde}}$ & $22.3138 \pm 0.7607^{c}$ \\
\hline 210 & $27.5347 \pm 1.0932^{\mathrm{cd}}$ & $31.5878 \pm 0.7750^{\mathrm{cde}}$ & $22.2293 \pm 0.2639^{c}$ \\
\hline 240 & $27.5347 \pm 0.1367^{\mathrm{cd}}$ & $31.3735 \pm 0.2572^{\mathrm{cde}}$ & $21.8489 \pm 1.1983^{c}$ \\
\hline 270 & $27.3375 \pm 0.3131^{\mathrm{d}}$ & $31.1592 \pm 0.5196^{\mathrm{e}}$ & $18.2567 \pm 0.3803^{d}$ \\
\hline 300 & $27.1402 \pm 0.2464^{\mathrm{d}}$ & $31.0306 \pm 0.1485^{\mathrm{e}}$ & $17.8341 \pm 0.3191^{\mathrm{d}}$ \\
\hline
\end{tabular}

${ }^{*}$ Means followed by the same letter in the same column do not differ significantly $(\mathrm{P}>0.05)$ by Tukey's test.

an inactivation rate of $0.06 \% / \mathrm{min}$. At $55^{\circ} \mathrm{C}$, the reduction was $11.1 \%$ with inactivation rate of $0.04 \% / \mathrm{min}$. Finally, at $60^{\circ} \mathrm{C}$, the enzyme activity reduced $25 \%$ after 90 minutes of storage, with inactivation rate of $0.17 \% / \mathrm{min}$ (Figure $3 \mathrm{~B}$ ).

A significant decrease in the enzyme activity from $68.47 \%$ to $42.37 \%$ was observed for $\mathrm{K}$. lactis at $30{ }^{\circ} \mathrm{C}$ within 120 minutes, while no significant losses were observed from 120 to 240 minutes, which ranged from $42.37 \%$ to $41.98 \%$ (Table 3 ). Similar behavior was observed at $35{ }^{\circ} \mathrm{C}$. However, a high reduction in enzyme activity was observed at $40{ }^{\circ} \mathrm{C}$ within 90 minutes of storage, with a reduction from $68.47 \%$ to $7.91 \%$ (Table 3 ). Other studies have shown that the increase in temperature leads to losses in enzyme activity of K. lactis (Cavaille-Lefebvre \& Combes, 1998; Zhou \& Chen, 2001).

Small variations in enzyme stability were observed for the enzyme from $A$. oryzae, at $50^{\circ} \mathrm{C}$ and $55^{\circ} \mathrm{C}$ during 300 minutes of storage. At $60{ }^{\circ} \mathrm{C}$, no significant losses were found within 90 minutes, with a significant reduction from $31.4 \%$ to $18.2 \%$ from 90 to 270 minutes (Table 4). Several authors (Ateş \& Mehmetoğlu, 1997; Dhaked et al., 2005; Zhou \& Chen, 2001) have reported that the increase in temperature directly affects the enzyme activity, i.e., the higher the temperature the faster the enzyme inactivation. However, in this study, the enzyme from $A$. oryzae was stable with increasing temperature to $60^{\circ} \mathrm{C}$, even after 5 hours, differing from the results obtained by Haider
\& Husain (2007), who found that the enzyme from A. oryzae lost about $60 \%$ of activity after 6 hours at $60^{\circ} \mathrm{C}$. Additional tests were carried out to evaluate the thermal stability of the enzyme from $K$. lactis and $A$. oryzae at 70 and $80^{\circ} \mathrm{C}$, and no enzyme activity was observed for both enzymes.

\section{Conclusions}

Significant differences were observed for the enzyme activity from both the yeast $K$. lactis and the filamentous fungus $A$. oryzae in lactose hydrolysis. The variables enzyme concentration, temperature, and $\mathrm{pH}$ significantly affect hydrolysis reactions. The highest activities were observed at $40^{\circ} \mathrm{C}$ and $\mathrm{pH} 7.0$ for the enzyme from K. lactis, and at $55^{\circ} \mathrm{C}$ and pH 5.0 for the enzyme from $A$. oryzae when tested in lactose substrate. Higher enzyme activity was observed in UHT milk when compared to skimmed milk, for both enzymes. The enzyme from $A$. oryzae was not effective in the target substrates due the differences between $\mathrm{pH}$ of milk and the optimum $\mathrm{pH}$ range for enzyme activity. However, with respect to thermal stability, it was observed that the enzyme from $A$. oryzae had higher heat resistance when compared to that from $K$. lactis. The knowledge about the characteristics of $\beta$-galactosidase from $K$. lactis and $A$. oryzae allows using it more efficiently in many industrial processes and product formulations, and as guidelines for direct consumption by lactose intolerant individuals. 


\section{Acknowledgements}

The authors would like to thank Coordenação de Aperfeiçoamento de Pessoal de Nível Superior - CAPES/Brazil for the financial support, and KROTON/UNOPAR for school and masterships.

\section{References}

Ateş, S., \& Mehmetoğlu, Ü. (1997). A new method for immobilization of $\beta$-galactosidase and its utilization in a plug flow reactor. Process Biochemistry, 32(5), 433-436. http://dx.doi.org/10.1016/S00329592(96)00101-X

Bódalo, A., Gómez, E., Gómez, J. L., Bastida, J., Máximo, M. F., \& Díaz, F. A. (1991). Comparison of different methods of $\beta$-Galactosidase immobilization. Process Biochemistry, 26(6), 349-353. http://dx.doi. org/10.1016/0032-9592(91)85025-J.

Borges, P. F. Z., Sgarbieri, V. C., Jacobucci, H. B., Pacheco, M. T. B., \& Baldini, V. L. S. (2000). Produção piloto de proteínas de soro de leite bovino: composição e valor nutritivo. Brazilian Journal of Food Technology, 4(1), 1-8.

Campos, T. C. A. S., D’Almeida, W. K., Alegro, L. C. A., Roig, S. M., \& Suguimoto, H. H. (2009). Utilização da $\beta$-galactosidase na hidrólise da lactose do leite em baixa temperatura. Unopar científica. Ciências Biológicas e da Saúde, 11(4), 51-54.

Carminatti, C. A. (2001). Ensaios da hidrólise enzimática da lactose em reator a membrana utilizando beta-galactosidase Kluyveromyes lactis (Dissertação de mestrado). Universidade Federal de Santa Catarina, Florianópolis.

Cavaille-Lefebvre, D., \& Combes, D. (1998). Irreversible high pressure inactivation of beta-galactosidase from Kluyveromyces lactis: comparison with thermal inactivation. Journal of Biotechnology, 61(2), 85-93. http://dx.doi.org/10.1016/S0168-1656(98)00007-8. PMid:9654742.

Dhaked, R. K., Alan, S. I., \& Singh, L. (2005). Characterization of $\beta$-galactosidase from an Antartic Bacillus sp. Indian Journal of Biotechnology, 4, 227-231.

DuBois, M., Gilles, K. A., Hamilton, J. K., Rebers, P. A., \& Smith, F. (1956). Colorimetric method for determination of sugars and related substances. Analytical Chemistry, 28(3), 350-356. http://dx.doi. org/10.1021/ac60111a017.

Evangelista, J. (1998). Tecnologia de alimentos (2nd ed.). São Paulo: Atheneu.

Ferreira, C. L. L. F. (1997). Valor nutritivo e bioterapêutico de leites fermentados. In A. L. S. Lerayer \& T. J. G. Salva. Leites fermentados e bebidas lácteas: tecnologia e mercado (Chap. 1, pp. 1-7). Campinas: ITAL.

Goursaud, J. (1985). O leite de vaca: composição e propriedades físicoquímicas. In F. M. Luquet. O leite: do úbere à fábrica de laticínios (Chap. 1, pp. 31-56). Portugal: Publicações Europa-America Ltda.

Guidini, C. Z., Fischer, J., Resende, M. M., Cardoso, V. L., \& Ribeiro, E. J. (2011). $\beta$-galactosidase of Aspergillus oryzae immobilized in an ion exchange resin combining the ionic-binding and crosslinking methods: Kinetics and stability during the hydrolysis of lactose. Journal of Molecular Catalysis. B, Enzymatic, 71(3-4), 139-145. http://dx.doi.org/10.1016/j.molcatb.2011.04.010.

Guidini, C. Z., Fischer, J., Santana, L. N. S., Cardoso, V. L., \& Ribeiro, E. J. (2010). Immobilization of Aspergillus oryzae beta-galactosidase in ion exchange resins by combined ionic-binding method and cross-linking. Biochemical Engineering Journal, 52(2-3), 137-143. http://dx.doi.org/10.1016/j.bej.2010.07.013.

Haider, T., \& Husain, Q. (2007). Calcium alginate entrapped preparations of Aspergillus oryzae $\beta$-galactosidase: its stability and applications in the hydrolysis of lactose. International Journal of Biological Macromolecules, 41(1), 72-80. http://dx.doi.org/10.1016/j. ijbiomac.2007.01.001. PMid:17298841.

Haider, T., \& Husain, Q. (2008). Hydrolysis of milk/whey lactose by $\beta$-galactosidase: a comparative study of stirred batch process and packed bed reactor prepared with calcium alginate entrapped enzyme. Chemical Engineering and Processing: Process Intensification, 48(1), 576-580. http://dx.doi.org/10.1016/j.cep.2008.02.007.

Hobman, P. G. (1984). Review of process and products for utilization of lactose in deproteinated milk serum. Journal of Dairy Science, 67(11), 2630-2653. http://dx.doi.org/10.3168/jds.S0022-0302(84)81624-0.

Hronska, H., Grosova, Z., \& Rosenberg, M. (2009). Hydrolysis of lactose in milk by Kluyveromyces lactis beta-galactosidase immobilized in polyvinylalcohol gel. Journal of Food and Nutrition Research, 48(2), 87-91.

Jelen, P. (1983). Reprocessing of whey and other dairy wastes for use as food ingredients. Food Technology, 37(2), 81-84.

Jurado, E., Camacho, F., Luzón, G., \& Vicaria, J. M. (2002). A new kinetic model proposed for enzymatic hydrolysis of lactose by $\beta$-galactosidase from Kluyveromyces fragilis. Enzyme and Microbial Technology, 31(3), 300-309. http://dx.doi.org/10.1016/S0141-0229(02)00107-2.

Kardel, G., Furtado, M. M., \& Lorenço, J. P. M., No. (1995). Lactase na indústria de laticínios. Revista do Instituto de Laticínios "Cândido Tostes", 50(294), 15-17.

Mahoney, R. R. (1997). Lactose: enzymatic modification. In P. F. Fox (Eds.), Lactose, water, salts and vitamins (Advanced Dairy Chemistry, Vol. 3, pp. 77-125). New York: Springer.

Manan, D. M. A., Karin, A. A., \& Kit, W. K. (1999). Lactose content of modified enzyme- treated "Dadih". Food Chemistry, 65(4), 439-443. http://dx.doi.org/10.1016/S0308-8146(98)00174-5.

McSweeney, P. L. H., \& Fox, P. F. (2009). Advanced dairy chemistry: lactose, water, salts and minor constituents (3rd ed.) New York: Springer.

Oliveira, C. C. M. (2005). Produção de beta-galactosidase por levedura recombinante Desenvolvimento de um sistema de produção estável (Dissertação de mestrado). Universidade do Minho, Braga.

Pereira, M. C. S., Brumano, L. P., Kamiyama, C. M., Pereira, J. P. F., Rodarte, M. P., \& Pinto, M. A. O. (2012). Lácteos com baixo teor de lactose: uma necessidade para portadores de má digestão da lactose e um nicho de mercado. Revista do Instituto de Laticínios Cândido Tostes, 389(67), 57-65. http://dx.doi.org/10.5935/2238-6416.20120079.

Pivarnik, L. F., Senecal, A. G., \& Rand, A. G. (1995). Hydrolytic and transgalactosylic activities of commercial $\beta$-galactosidase (lactase) in food processing. Advances in Food and Nutrition Research, 38, 1-102. http://dx.doi.org/10.1016/S1043-4526(08)60083-2. PMid:15918291.

Ribeiro, G. P., Freitas, F. F., \& Ribeiro, E. J. (2005). Estudo da cinética da reação de hidrólise de lactose por $\beta$-galactosidade de Aspergillus oryzae. In: Anais do Congresso Brasileiro de Engenharia Química em Iniciação Científica (Chap. 6). Campinas- SP.

Santos, A., Ladero, M., \& García-Ochoa, F. (1998). Kinetic modeling of lactose hydrolysis by a $\beta$-galactosidase from Kluyveromyces fragilis. Enzyme and Microbial Technology, 22(7), 558-567. http://dx.doi. org/10.1016/S0141-0229(97)00236-6.

Şener, N., Kılıç Apar, D., \& Özbek, B. (2006). A modelling study on milk lactose hydrolysis and $\beta$-galactosidase stability under sonication. Process Biochemistry, 41(7), 1493-1500. http://dx.doi.org/10.1016/j. procbio.2006.02.008.

Statsoft. (2007). Statistic (data analysis software system), version 10.0. Tulsa: Statsoft Inc. Available from: www.satsoft.com

Trindade, R. A., Rego, T. V., \& Burkert, C. A. V. (2004). Influência da temperatura na hidrólise da lactose do soro de queijo por 
B-Galactosidase de Kluyveromyces Lactis (Lactozym ${ }^{\circledR}$ 6500l) livre e imobilizada. Rio Grande: Universidade Federal do Rio Grande, Escola e Química e Alimentos, Laboratório de Engenharia de Bioprocessos.

Vitolo, M. (2001). Aplicações de enzimas na tecnologia de alimentos. In E. Aquarone. Biotecnologia industrial: biotecnologia na produção de alimentos (Chap. 14, pp. 387-420). São Paulo: Edgard Blücher Ltda.
Zadow, J. G. (1984). Lactose - properties and uses. Journal of Dairy Science, 67(11), 2654-2679. http://dx.doi.org/10.3168/jds.S00220302(84)81625-2.

Zhou, Q. Z. K., \& Chen, X. D. (2001). Effects of temperature and pH on the catalytic activity of the immobilized $\beta$-galactosidase from Kluyveromyces lactis. Biochemical Engineering Journal, 9(1), 33-40. http://dx.doi.org/10.1016/S1369-703X(01)00118-8. 